\title{
Stream Sediment Geochemical Survey on Metamorphic Rock, Kolaka, Southeast Sulawesi, Indonesia.
}

\author{
Adi Tonggiroh \\ Department of Geological Engineering, Hasanuddin University, Gowa, South Sulawesi, Indonesia.
}

\author{
* Corresponding author :atonggiroh@ gmail.com \\ Tel.:+81288269962 \\ Received: August 7, 2020; Accepted: Sept 10, 2020. \\ DOI: 10.25299 /jgeet.2020.5.4.5433
}

\begin{abstract}
The aim of this research is to conduct surface geological mapping to determine the lithology that underlies the linear geochemical characteristics of $\mathrm{Ag}, \mathrm{As}, \mathrm{Cd}, \mathrm{Co}, \mathrm{Cu}, \mathrm{Fe}, \mathrm{Mn}, \mathrm{Ni}, \mathrm{Pb}, \mathrm{Zn}$ by using stream sediment data. Furthermore, to know the distribution of these elements lithologically in the area. This study uses 10 sediment stream samples of 80 mesh up to 100 mesh which then chemical elements are analyzed with AAS. Alteration mineralization occcurs in quartz chlorite geneiss: quartz, epidote, chlorite, muscovite, sericite, calcite, monmorillonite, pyrite, sphalerite, bornite and chalcopyrite. Based on linearity analysis elements are grouped into three according to the significant value of 0.3 to 0.9 , which are significant elements $\mathrm{Ni}, \mathrm{Pb}=\mathrm{Cu}=\mathrm{Zn}$ and $\mathrm{As}$, abundant elements in lateralization and sulphide mineralization. The geochemical characteristics of the Ni element reflect the associated distribution of ultramafic weathering which results are transported regionally and together with other elements as stream sediments. While $\mathrm{Pb}, \mathrm{Cu}, \mathrm{Zn}$ are related to quartz veins in metamorphic or intrusive rocks.
\end{abstract}

Keywords: stream sediment, metamorphic rocks, kolaka.

\section{Introduction}

Sediment stream is an exploratory geochemical method that may probability the source of heavy metals. Stream sediments is one of Geochemical technique used in this research, this method is widely used for various applications (Rollinson, 2014).

Included as a conventional method is not efficient in determining a mineral deposit hidden deep beneath various types of covering layers (Yilmaz et al., 2015) wich the layer begins with weathering of mineralized rocks and soil which then enters streams to form sediment, it is often difficult to determine the source of mineralization. Such problems are typical of geochemical patterns (Fletcehr, 1990, 2005).

Inefficiency of Geochemical stream sediment method is due to the difficulty in determining mineral deposits that are hidden far below various types of bed layers. The difficulty in analyzing stream sediment data are based entily on variations in data sources that are unevenly distributed (Farahbakhsha et al.,2019). Various type, shapes and sizes of mineral grains can come from the river walls, headwaters or mineralization that is exposed far from rivers. However, its efficiency lies in the location of sampling point along river pattern.

According to regional geology, the Upstream of Ulunggolaka River is located in the northern part of Kolaka Regency (not part of the study area) and flows over the metamorphic belt (Pompangeo complex) predominantly composed of interbanded phyllitic marble, calcareous phyllite, graphitic schist and quartzite (Parkinson, 1988) and ultramafic and metamorphic complex. Pompangeo complex contains gold in quartz veins (Mawaleda et al.,2017) which strongly indicate to have weathered, transported and settled as gold placer. Strong indications of the Placer gold deposits are results of surface processes and their formation in relation to the regional geomorphological evolution. Many placer gold models (Herail et al., 1989).

The application of the geochemical sedimentary stream method around the Ulunggolaka River is based on the terrigenous sediment texture which is controlled by transportation, the morphology of the temporary depositional environment and its mineralogical composition. The main goal of this study (1) geological surface mapping to determine the lithology that underlies the basic aim (2) to determine the linear geochemical characteristics of $\mathrm{Ag}, \mathrm{As}, \mathrm{Cd}, \mathrm{Co}, \mathrm{Cu}, \mathrm{Fe}, \mathrm{Mn}, \mathrm{Ni}$, $\mathrm{Pb}, \mathrm{Zn}$ by using stream sediment data.

This study uses a statistical analysis approach to determine the environmental distribution of elements in which elements in heavy minerals can decompose and settle in stream sediments, so that interpreted geochemical data with statistics becomes more effective (Ali et al., 2006) so the result of the elemental distribution can correlates to primary deposition.

\section{Location And Accessibility}

The study area consists of mountaineous morphology composed of well-exposed schist and limestone unit. The study area covers about $4 \mathrm{~km} 2$ which is connected by brick roads from Latambaga, Kolaka Regency, Southeast Sulawesi province and footpaths leading to the Ulunggolaka River (Figure 1).

\section{Regional Geological Setting}

Research areas is situated at East Sulawesi tectonic province which are characterized by ophiolite and metamorphic rocks (Sukamto, 1982) and comes under Geological Map Lasusua-Kendari Sheet (Rusmana et al., 1993). It consists of the Mekongga Metamorphic Complex (Pzm), intrusive rocks (PTR (g)), Tokala Formation (TRJt), Ultramafic Complex (Ku), and Alluvial (Qa). Intrusion rocks consist of aplite quartz, andesite, quartz latite (Rusmana et al., 1993) and dacite (White et al, 
2014) that intruded the metamorphic paleozoic rocks which are estimated to be of the Perem age.

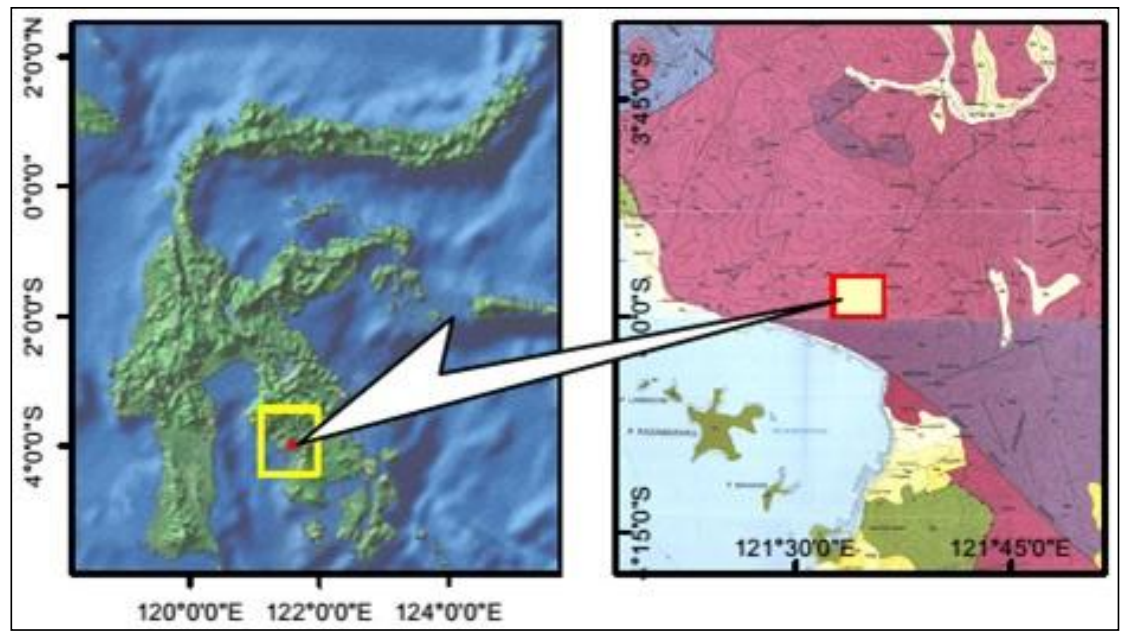

Fig 1. Map of research Area

The distribution of metamorphic, limestone (Figure 2) and ultramafic rocks is bordered by the Kolaka Sinistral Shear fault which generally runs in the northwest-southeast direction which also contains dacite intrusion (White et al., 2014).

The distribution of metamorphic, limestone (Figure 2) and ultramafic rocks is bordered by the Kolaka Sinistral Shear faut which generally runs in the northwest-southeast direction which also contains dacite intrusion (White et al., 2014).

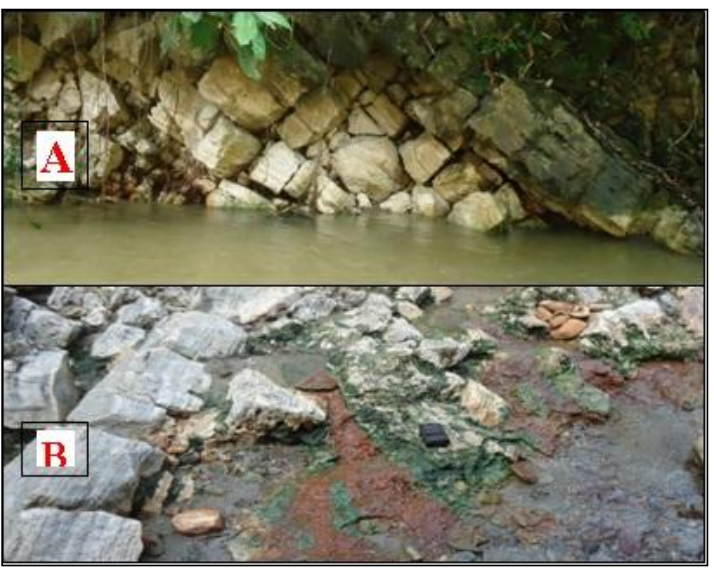

Fig 2. (A) Limestone outcrop (B) Schist outcrop and oxydation.

\section{Methodology}

Samples are taken from the composite river sediment layer at the top to the bottom, where the top is dominated by finesized fraction while the bottom is of coarse-sized fractions dominance. Randomly the distance of the sample point takes into account the conditions of the river bed, topography and lithology, therefore at the sampling pont it is necessary to ensure that sufficiently sized fractions are available. If the river bed is dominated by coarse fractions, 80 mesh to 200 mesh sieves are required.

A total of 10 samples were taken from stream sediments with metamorphic rocks dominance (UL 01, UL02, UL03, UL 04, UL05, UL06, UL07, UL08, UL09, UL10) at different geographical coordinates (Figure 3).

Application of statistical linearity analysis to identify domains of the geochemical similarity and map the analyzed results to visualize the relationship between geochemical elements, mineralization and lithology at the study area. overall analysis of stream sediment composition data is used to obtain the amount of elements and its geochemical properties upon metamorphic rock domains.

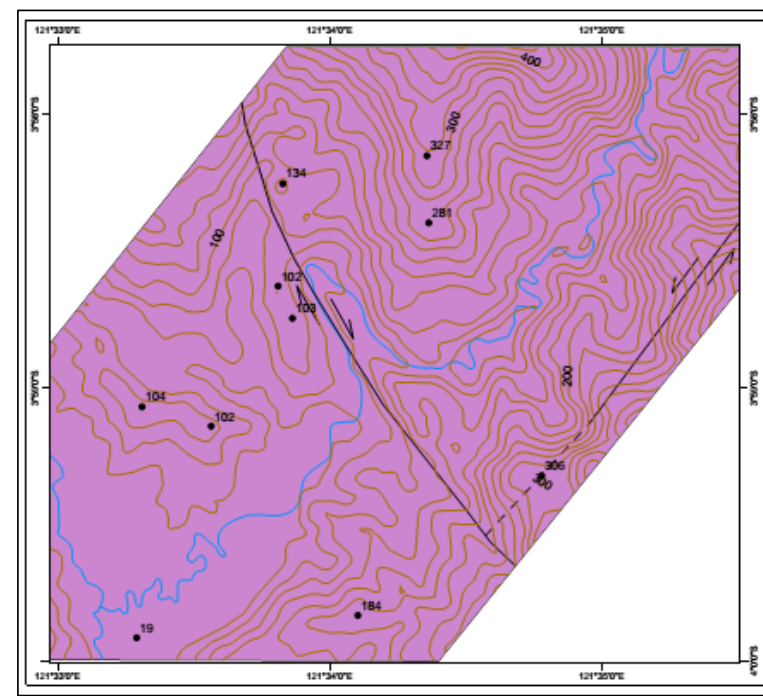

Fig 3. Geological Map and coordinates of Example of streams sediment.

Each sample is placed in a polyethylene bag to be dried by an oven at a temperature of $100 \mathrm{oC}$ (approximately 1 hour) then smoothed with a preparation machine at the Laboratory of Sedimentology Dept of geological engineering. Hasanuddin University. Furthermore, each sample is divided into 2 bags, namely: one bag for grain size analysis and for chemical composition analysis with Atomic Absorption Spectrometry (AAS) including: $\mathrm{Ag}, \mathrm{As}, \mathrm{Cd}, \mathrm{Co}, \mathrm{Cu}, \mathrm{Fe}, \mathrm{Mn}, \mathrm{Ni}, \mathrm{Pb}, \mathrm{Zn} .4$ samples are taken from rock outcrops (2 samples at station UL01, UL08 and 2 samples at UL05, UL07) and then is prepared into a polish section to determine the texture of the metal minerals. And one thin section from metamorphic outcrop with a size of $<0.03 \mathrm{~mm}$ for petrographic analysis.

\section{Results and Discussions}

Consentration of $\mathrm{As}, \mathrm{Cd}, \mathrm{Co}, \mathrm{Cu}, \mathrm{Fe}, \mathrm{Mn}, \mathrm{Ni}, \mathrm{Pb}, \mathrm{Zn}$ considering topographic factors, lithology, alteration mineralization, sediment grains and drainage patterns.

\subsection{Topography, Drainage system and}

Geological Structure 
The mountaineous topography of the study area is influenced by the regional geological structure namely; shear fault (sinistral fault) which act in northwest-southeast direction (Rusmana, et al., 1993). The influence of the sinistral fault structure on the topography forms the denritic drainage pattern of the Ulunggolaka River. And cause the exposer of the mineralized metamorphic complexes. Identical topographic appearance of metamorphic rocks contacting with other lithology can be observed upstream of the Ulunggolaka River, namely east and west (Figure 4).



Fig. 4. (A) Topography of Ulunggolaka river.

\subsection{Lithology}

Mapped rock outcrops are dominated by metamorphic rocks consisting of muscovite-Quartz Schist, Quartz-Chlorite Gneiss, and unmapped outcrops namely limestone, serpentinite, andesite, wackestone.

\subsection{Mineralisation and Alteration}

Mineralization on quartz chlorite geneiss: quartz, epidote, chlorite, muscovite, sericite, calcite, monmorillonite, pyrite mineral, sphalerite, bornite and chalcopyrite. This mineral assemblage are grouped into four, namely: (1) epidote, chlorite, quartz (2) chlorite, muscovite, quartz (3) calcite, sericite, quartz (4) calcite, seirisit, montmorillonite. Microscopic observation of the subhedral pyrite texture indicates a step of pyrite replacing sphalerite (Figure 5).

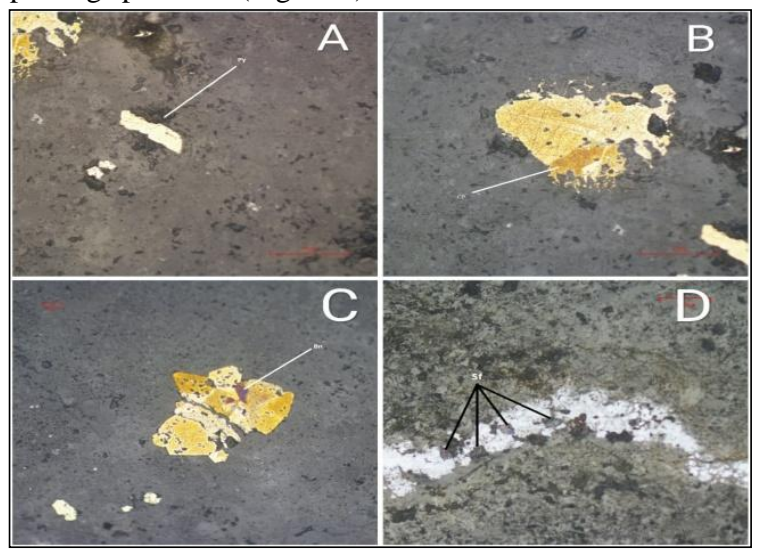

Fig 5. Photomicrgraph (A) pyrite (B) chalcopyrite (C) Bornite (D) sphalerite.

\subsection{Characteristics of stream sediment grain}

The size distribution of sediment material consists o coarse sand to medium sand. These size variations are uneven, coarse sand size (UL01 to UL02), medium size sand (UL03-UL04), coarse to fine size sand (UL05,07,09,10) and sandy clay (UL06,08). This size variation is controlled by morphology, rock resistance to weathering and river currents.

\subsection{Elements Statistic}

The results of chemical analysis of sediment samples from the study area show $\mathrm{Cu}, \mathrm{Zn}, \mathrm{Ni}, \mathrm{Pb}$, As have a fairly high concentration while the elements $\mathrm{Fe}, \mathrm{Co}, \mathrm{Ag}$ have a low concentration. The tendency of positive skewness is low in $\mathrm{Cu}$, $\mathrm{Zn}, \mathrm{Pb}, \mathrm{Co}$ and high in $\mathrm{Fe}$ and $\mathrm{As}$ except $\mathrm{Ni}$. Thus $\mathrm{Ni}$ and $\mathrm{As}$ are elements that are in each group (Table 1).

Table 1. stream sediment Elements

\begin{tabular}{lllllll}
\hline \multicolumn{1}{c}{ Element } & \multicolumn{1}{c}{ Detec. Lim } & Mean & \multicolumn{1}{c}{ St.D } & \multicolumn{1}{c}{ Max. } & Min. & Skew \\
\hline $\mathrm{Cu}$ & $2 \mathrm{ppm}$ & 23.2000 & 7.6129 & 35.0000 & 12.0000 & 0.548 \\
$\mathrm{Zn}$ & $2 \mathrm{ppm}$ & 65.3000 & 5.2926 & 75.0000 & 58.0000 & 0.734 \\
$\mathrm{Ni}$ & $4 \mathrm{ppm}$ & 12.4000 & 3.1340 & 17.0000 & 7.0000 & -0.22 \\
$\mathrm{Fe}(\%)$ & 0.01 & 2.7370 & 0.4261 & 3.6500 & 2.3000 & 1.352 \\
$\mathrm{~Pb}$ & $4 \mathrm{ppm}$ & 23.5000 & 7.7064 & 39.0000 & 13.0000 & 0.648 \\
$\mathrm{As}$ & $50 \mathrm{ppm}$ & 58.3000 & 22.1563 & 120.0000 & 49.0000 & 2.928 \\
$\mathrm{Co}$ & $4 \mathrm{ppm}$ & 10.0000 & 1.8257 & 13.0000 & 8.0000 & 0.548 \\
$\mathrm{Ag}$ & $1 \mathrm{ppm}$ & 0.0900 & 0.0000 & 0.0900 & 0.0900 & - \\
\hline
\end{tabular}

\subsection{Linierity}

$\mathrm{Ni}$, As groups have other elemental variables with the same linearity. To classify variables, linearity analysis is performed on $\mathrm{Cu}, \mathrm{Zn}, \mathrm{Fe}, \mathrm{Pb}, \mathrm{Co}$, Agby using IBM SPSS v. 25 software. The following variables are obtained: (1) $\mathrm{Ni}$, and $\mathrm{Co}, \mathrm{Cu}, \mathrm{Pb}$, $\mathrm{Fe}(2) \mathrm{Zn}$, and $\mathrm{Pb}, \mathrm{As}, \mathrm{Ni}, \mathrm{Cu}$ (3) As, and $\mathrm{Cu}, \mathrm{Zn}$. The number of variables still requires reduction and with cluster analysis produces two regression groups and Squared Euclidean Distance (SED), that is:

\subsubsection{Group $\mathrm{Ni}$ and $\mathrm{Co} \mathrm{Cu} \mathrm{Pb} \mathrm{Fe}$}

Ni linearity is very strong for Co $(y=2.4 x-13.2$; sig = 0.318; $\mathrm{df}=9.01$ ), but is weak for $\mathrm{Cu}, \mathrm{Pb}, \mathrm{Fe}$. Whereas Co have strong linearity with $\mathrm{Fe}(\mathrm{y}=1.333 \mathrm{x}+0.5 ; \mathrm{Sig}=0.996$; $\mathrm{df}=$ $237)$ and $\mathrm{Pb}$ have strong linearity with $\mathrm{Cu}(\mathrm{y}=0.833 \mathrm{x}+1.67)$. Thus, there are two groups, namely (1) $\mathrm{Ni}=\mathrm{Co}=\mathrm{Fe}$, the $\mathrm{Ni}$ component can be considered as an ultramafic content variable and a Co controller. Where the difference in Co geochemical variables is strong with a single component, it is considered a measure of argillaceousness in sediments (Kirkwood et al., 2016). (2) $\mathrm{Cu}$ and $\mathrm{Pb}$, showed that the concentration enriched in the sedimentary fraction originating from intrusive rocks. sedimentary fraction originating from intrusive rocks.

\subsubsection{Group $\mathrm{Zn}$ and $\mathrm{Pb} \mathrm{As} \mathrm{Ni} \mathrm{Cu}$}

$\mathrm{Zn}$ linearity is very strong for $\mathrm{Cu}$ (regression $\mathrm{y}=1.8 \mathrm{x}+47$; SED sig $=0.524 ; \mathrm{df}=19.33), \mathrm{Pb}(\mathrm{y}=3.2 \mathrm{x}+8 ; \mathrm{Sig}=0.128 ; \mathrm{df}$ $=5.59)$ and As $(\mathrm{y}=0.25 \mathrm{x}+45 ; \mathrm{Sig}=0.929 ; \mathrm{df}=19.33)$. But $\mathrm{Pb}$ and $\mathrm{Cu}(\mathrm{y}=0.833 \mathrm{x}+1.67)$ showed two independent variables with similar strenght.

Thus, according to SEDs on three variables, namely: (1) Ni (2) $\mathrm{Zn}=\mathrm{Pb}=\mathrm{Cu}$ (3) As. The similarity of $\mathrm{Pb}=\mathrm{Cu}$ is a strong indication of secondary sulfide formation which can also occur with $\mathrm{Zn}$, which is the intergrowth texture of the sphalerite. While the nature of As mobility in sediment flow can be 
accompanied by $\mathrm{Pb}$ which is likely to substitute for sulfide. As and $\mathrm{Cu}$ correlations $(\mathrm{R} 2=0.11)$ support a positive indication that both are located in a hydrothermal deposition system. This reinforces the suspicion that primary sulfide traces are originated from As and $\mathrm{Pb}$ (Figure 6).

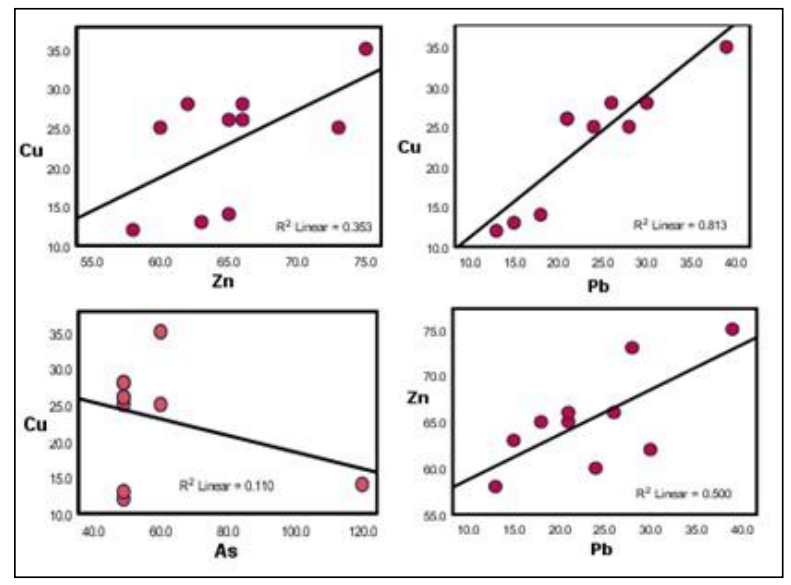

Fig 6. Linieritas elements

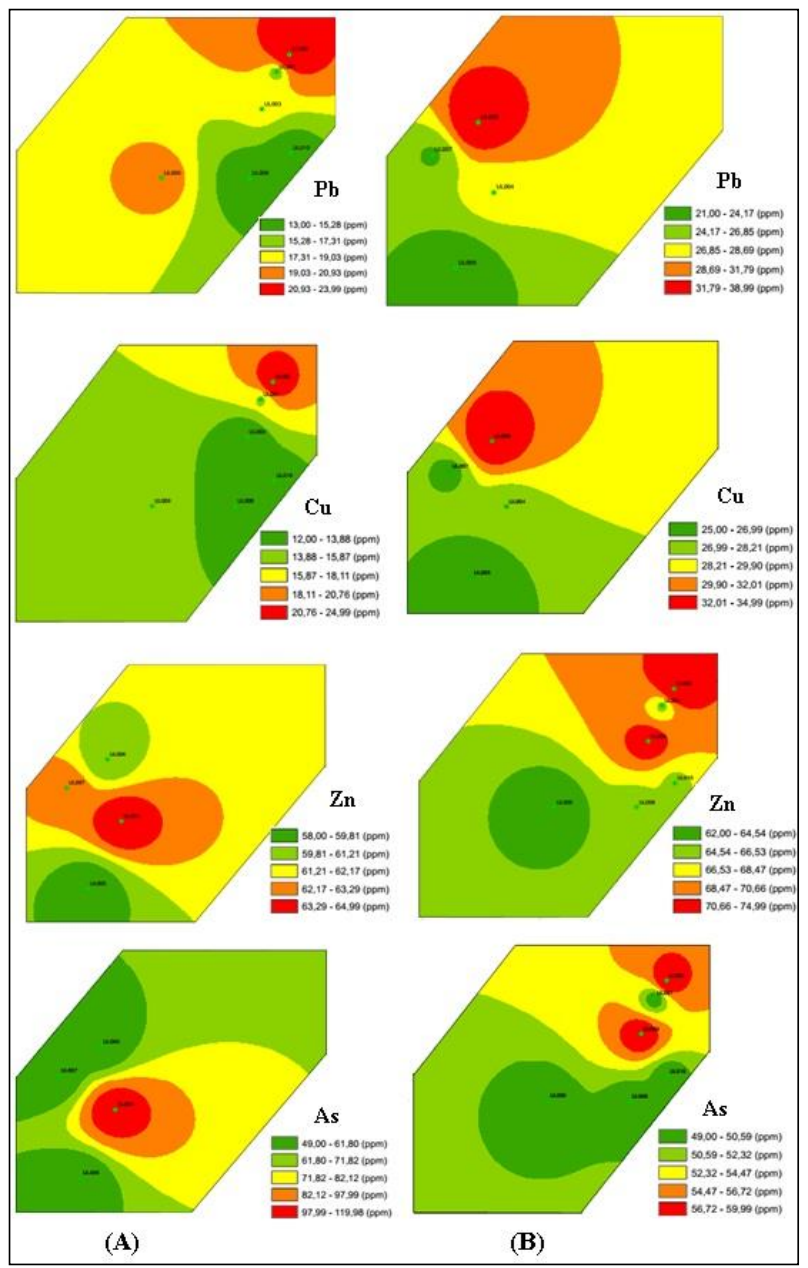

Fig 7. Elements distribution (A)west (B)east of Ulunggolaka

\subsection{Distribution}

The variable elements $\mathrm{Ni}, \mathrm{Zn}, \mathrm{Pb}, \mathrm{Cu}, \mathrm{As}$ are used to determine the distribution with the statistical formula: $1+3.3$ $\log \mathrm{n}, \mathrm{n}=$ the amount of data. Obtained five groups of each element and based on the pattern of river straightness and the independent variables are equally strong, there are differences and similarities in anomalies in the western and eastern parts.
In the western part, $\mathrm{Ni}$ is broadly oriented in the northwest and $\mathrm{Pb}, \mathrm{Cu}, \mathrm{Zn}$ is narrowly oriented spot. In the East, $\mathrm{Ni}$ is broadly oriented to the northeast and $\mathrm{Pb}, \mathrm{Cu}, \mathrm{Zn}$ is narrowly oriented. The general symptoms of $\mathrm{Ni}$ anomalies indicate regional contact with metamorphic and utramafic rocks in the northern part of the study area. This is reinforced by the distribution of Co. The elements $\mathrm{Pb}, \mathrm{Cu}, \mathrm{Zn}$ have the same distribution character except As (Figure 7).

\section{Conclusion}

Surface geological mapping shows the study area being composed of muscovite-Quartz Schist, Quartz-Chlorite Gneiss metamorphic rocks, where there are outcrops of limestone, serpentinite, andesite, wackestone. In metamorphic outcrops there are pyrite mineralization, sphalerites spread along the veins of quartz.

The application of linearity analysis groups three elements according to significant values of 0.3 to 0.9 , namely the significant elements of $\mathrm{Ni}, \mathrm{Pb}=\mathrm{Cu}=\mathrm{Zn}$ and $\mathrm{As}$, the abundant elements in lateralization and mineralization of sulfide. However, As is related to Au mineralization (Yang and Blum, 1999a). The geochemical characteristics of the Ni element reflect its association with the distribution of ultramafic weathering which are transported regionally together with other elements as stream sediments. Where as $\mathrm{Pb}, \mathrm{Cu}, \mathrm{Zn}$ are related to quartz veins in metamorphic or intrusive.

\section{References}

Ali, K., Cheng, Q., Li, W., Chen, Y., 2006. Multi-element analysis of stream sediment geochemistry data for predicting gold deposits in south-central Yunnan Province, China. Geochemistry Exploration, Environment, Analysis 6, 341-348.Doi : 10.1144/14677873/06-109

Farahbakhsha, E., Chandra, R., Eslamkish, T., Dietmar Müllera, R., 2019. Modeling geochemical anomalies of stream sediment data through a weighted drainage catchment basin method for detecting porphyry $\mathrm{Cu}-\mathrm{Au}$ mineralization. Geochemical Exploration 204, 12-32. Doi : 10.1016/j.gexplo.2019.05.003

Fletcher, W.K., 1990. Dispersion and behavior of gold in stream sediments, A contribution to the Canada/British Columbia Mineral Development Agreement. Open file, 1990-28.

Fletcher, W.K., Muda, J., 2005. Dispersion of gold in stream sediments in the Sungai Kuli region, Sabah, Malaysia. Geochemistry Exploration Environment Analysis 5(3), 211-214.Doi: 10.1144/1467-7873/03-036

Hérail, G., Fornari, M.,Rouhier, M. 1989, Geomorphological control of gold distribution and gold particle evolution in glacial and fluvioglacial placers of the Ancocala-Ananea Basin -Southeastern Andes of Peru. Geomorphology, 2, 369-383.Doi : 10.1016/0169-555X(89)90021-4

Kirkwood, C., Everett, P., Ferreira, A., Lister, B.,2016.Stream sediment geochemistry as a tool for enhancing geological understanding: An overview of new data from south west England. Geochemical Exploration 163,2840. Doi :10.1016/j.gexplo.2016.01.010

Mawaleda, M., Suparka, E., Chalid, I,A.,Basuki, N.I, Forster, M., Jamal., Kaharuddin., 2017. Hydrothermal alteration and timing of gold mineralisation in the Rumbia Complex Southeast Arm of Sulawesi Indonesia.IOP Conference Series Earth and Environmental Science 71(1): 012030.Doi : 10.1088/1755-1315/71/1/012030.

Parkinson, C.,1988.An outline of the petrology, structure and age of the pompangeo schist complex of central Sulawesi, Indonesia, The Island Arc 7,231-245.Doi : 10.1046/j.1440-1738.1998.00171.x. 
Rollinson, H.R., 2014. Using Geochemical Data: Evaluation, Presentation, Interpretation. Published by Routledge.

Rusmana, E., Sukido, Sukarna, D., Haryono, E., Simandjuntak, T.,1993. Peta Geologi Lembar Lasusua-Kendari, Sulawesi Skala 1: 250.000.

White, L.T.,Hall,R.,Armstrong, R.A., 2014. The age of undeformeddacite intrusions within the Kolaka Fault zone SE Sulawesi Indonesia. Asian Earth Sciences 94,105-112. Doi : 10.1016/j.jseaes.2014.08.014.13679120.

Yang, S.X., Blum, N., 1999a. A fossil hydrothermal system or a source-bed in the Madiyi Formation near the Xiangxi
Au-Sb-W deposit, NW Hunan, PR of China?. Chemical Geology 155, 151-169. Doi : 10.1016/S00092541(98)00146-6

Yilmaz, H.H., Sonmez, F,N.,Carranza, E.J.M.,2015. Discovery of $\mathrm{Au}-\mathrm{Ag}$ mineralization by stream sediment and soil geochemical exploration in metamorphic terrain in western Turkey. Geochemical Exploration, 158,55-73. Doi:10.1016/j.gexplo.2015.07.003

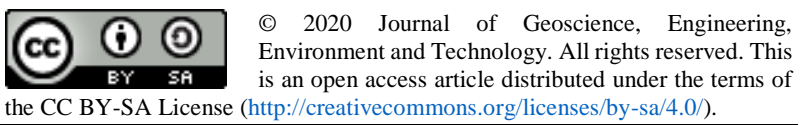

